\title{
Portuguese and Chinese Translation Teaching Based on Learners' Interests
}

\author{
Wenqiang Song* \\ Information Engineering University, Luoyang, Henan, 450002, China
}

\section{ARTICLE INFO}

Article history

Received: 17 July 2021

Revised: 25 July 2021

Accepted: 15 October 2021

Published Online: 30 October 2021

\section{Keywords:}

Translation teaching

Interest

Blended teaching

\begin{abstract}
The report of the 19th National Congress of the Party proposes to "accelerate the construction of first-class universities and first-class disciplines, and realize the connotative development of higher education." In the Declaration on the Construction of New Liberal Arts, it is mentioned that "we should insist on student-centeredness, output orientation and continuous improvement, build a quality assurance system for liberal arts education with Chinese characteristics, and construct a quality culture with liberal arts characteristics." In this context, undergraduate education in higher education institutions should further explore the integration of traditional teaching modes with modern technological means, and make use of high-tech means such as Internet+MOOC platform, flipped classroom and pair-sharing classroom to improve and innovate undergraduate teaching modes. This paper mainly tends to explore the translation teaching of Portuguese language majors in our college, which is not extensive but has certain significance.
\end{abstract}

teaching is often insufficient for the cultivation of students' interests, and the content of the lectures is so far removed from students' interests that students may find the learning content boring and find no intrinsic motivation, and are therefore reluctant to put in much effort to study the course content ${ }^{[3]}$. In the new Portuguese-Chinese translation teaching model, then, in order to address the lack of internal motivation of students' interests, it is first necessary to conduct a survey of students' interests, is conducted before the course is offered.

The instructor then prepares a targeted curriculum for the areas chosen by the participants. The areas provided in the table are relatively limited, as the actual implementation requires that the areas be developed in relation to specific realities, both in terms of the breadth of choice and the practicality of implementation, before which the instructor needs to consider two factors: firstly,

*Corresponding Author:

Wenqiang Song,

Information Engineering University, Luoyang, Henan, 450002, China;

Email:15138790207@163.com 
the instructor's knowledge of the relevant area; and secondly, the closeness of the subject content to translation methods and techniques. The content of the areas of interest set out mimics the areas listed by Coursera, but with specific pedagogical realities in mind. Therefore, Table 1 only provides a sample of references intended to show the areas of choice prepared for the development of translation courses in the major, and other teachers can and do make appropriate deletions to the content of the areas in this table according to their own familiarity with the areas. It should be made clear that in this table, students may only select one of the areas as their major and another as their minor for subsequent translation courses. Table 1-2 show a sample of the choices made by the students in the class. The table shows that Elsa was most interested in the area of literature and chose it as the main course for her future translation course, with music as the next most interesting area and chose it as a minor.

Table 1. Area of interest questionnaire

\begin{tabular}{|l|c|l|}
\hline Name & Area & (tick) \\
\hline \multirow{4}{*}{ Literature } & \\
\cline { 2 - 3 } & Arts & \\
\cline { 2 - 3 } & Military & \\
\cline { 2 - 3 } & Economy & \\
\hline & Philosophy & \\
\hline & Music & \\
\hline & Sports & \\
\hline
\end{tabular}

Table 2. Area of interest questionnaire

\begin{tabular}{|c|c|c|}
\hline Name & Area & (tick) \\
\hline \multirow{4}{*}{ Elsa } & Literature & $\sqrt{ } 1$ \\
\hline & Arts & \\
\hline & Military & \\
\hline & Economy & \\
\hline & Philosophy & \\
\hline & Music & $\sqrt{ } 2$ \\
\hline & Sports & \\
\hline
\end{tabular}

The interest of the learners is the inexhaustible motivation of the learners. In the traditional teaching mode, the cultivation of the learners' interest is often insufficient, the connection between the content of the lessons and the interest is not systematic, not lasting and too single, the learners may find the learning content boring and often do not want to make great efforts to study. By categorizing the different areas and allowing students to make their own choices, it largely reflects the students' willingness, interest and desire to learn something, so that if they have a goal and an orientation, they will be more committed to their studies. Once you know the main areas of interest chosen by the students, you need to refine a specific topic as the name of the course offered, which requires the students themselves to choose accordingly within the framework of the specific area.

Table 3. Name of the subject of the course offered

\begin{tabular}{|c|c|c|}
\hline Name & Area & Specific Theme \\
\hline Bruno & Sports & History of the NBA and some famous players \\
\hline Elsa & Literature & Paulo Coelho's work and character appreciation \\
\hline Noé & Arts & Portuguese blue and white porcelain art \\
\hline
\end{tabular}

The table shows the range of topics chosen and their content. We can also see that the choice of topics varies according to the interests of the students, and that this part needs to be reviewed by the instructor to assess the practicality and feasibility of the course, and to expand and reduce the range of topics without changing the interests of the students. After completing this step, the instructor will then begin to collect materials on the topics chosen by the participants, combining translation theories and methods, as well as the translation skills to be taught, using the content of the topics as a carrier and the theories and methods as a core, writing behind-the-scenes scripts, recording teaching videos, and post-processing them to eventually form a teaching module based on the interests of the participants.

\section{Implementation Phase}

The basic form of the implementation phase is network + classroom, which is mainly supported by the interestbased translation courses prepared by the instructor on the network platform, through independent study and submission of corresponding assignments. The online platform is the center of the students' self-learning, and it is also a key point of this mode for the teaching reform, and the explanation of knowledge and the discussion and Q\&A should be reflected in this link; in the classroom, the instructor always focuses on the core of translation theory, translation methods and translation skills, and then makes supplementary explanations for the important issues of a lesson, answers the questions that appear in the students' online learning, and then through specific examples and exercises. The instructor will consolidate the students' mastery of what they have learnt, disseminate and transfer, and use examples on different topics to make them realize that the same translation methods can be applied in different fields, deepening their grasp of the core of the course, i.e. translation methods and translation skills. 


\subsection{Basic Preparation}

The following basic preparations should be made for the implementation of this teaching model: firstly, in the context of the current semester, a survey of the distribution of the participants' time after school to get an idea of the time they can spend on e-learning, as shown in Table 4 Questionnaire on time after class (Bruno as an example).

\subsection{Content of Lectures}

The content of the lectures has to reflect the specific interests of the participants but not deviate from the requirements of the course in translation, and therefore has to be planned in terms of the specific arrangements. In simple terms, content $=$ interest + synchronization .

Interest-based means that the teaching of the translation course should be in line with the participants' previous knowledge of the chosen field, and that the translation methods and techniques to be taught should be integrated into the introduction to the field, so that the participants can use their own strengths and understand the essence more quickly in concrete translation practice. For example, when introducing the translation of action modifiers, such as the phrase "The students entered the school, singing and laughing", "Os alunos entraram na escola, cantando e rindo "The phrase "cantando e rindo" is an adverbial verb used in Portuguese to modify the state of the students entering the classroom, and when the instructor wants to talk about this point, based on the interest-based teaching model, we change the form of the sentence in the online video platform that is close to the learner's topic, changing into a new form where the video camera is given to the expression of a famous player. The following sentence was given at this point: " $A$ animação da torcida de basquetebal entrou no estádio, cantando e dançando, mas nesta altura, Kobe era extremamente tranquilo. "The use of "cantando e dançando" is also a subjunctive verb that modifies the way the cheerleaders enter the court, however, based on the participants' interest in the NBA, this cut is very appropriate and very natural to accept.

Synchronicity means that each participant receives the translation knowledge in sync with each lesson. Generally speaking, each student has only one translation lesson per week, so the online resources are updated once a week, because the specific content of individual students' learning is different, and the introduction of relevant translation methods and translation techniques is the same, so that the instructor can focus on solving students' problems in class and give more examples to deepen other students' comprehensive understanding and digestion of the knowledge explained. This also allows for a concentration of scattered learning in the classroom. This is an important aspect of ensuring that classroom teaching exists in this mode.

The content of the lectures is based on the translation techniques described in the Portuguese-Chinese translation textbooks, but we optimize the content of the lectures, for example for the "repetition method" technique, we get the following content.

The "repetition method" means that in Portuguese the language often uses other components to replace repetitive parts and link them to the context to form fuller sentences. In Chinese, however, this is not so often the case, and it is customary to use "repetition" to complete the

Table 4. Questionnaire on time after class (red for busy, green for free)

\begin{tabular}{|c|c|c|c|c|c|c|c|}
\hline Name & Class session & Monday & Tuesday & Wednesday & Thursday & Friday & Saturday \\
\hline \multirow{7}{*}{ Bruno } & 1 & & & & & & \\
\hline & 2 & & & & & & \\
\hline & 3 & & & & & & \\
\hline & 4 & & & & & & \\
\hline & 5 & & & & & & \\
\hline & 6 & & & & & & \\
\hline & 7 & & & & & & \\
\hline
\end{tabular}


context, which is a technique used in Portuguese-Chinese translation. For example, "A casa de Tino, está situada no Parque Natural, numa aldeia chamada Vale de Mu,a cinco minutos do Porto." translates as. "Tino's family lives in a natural park in a small mountain village called $\mathrm{Mu}$ Valley, five minutes from the port." In this example, in the original Portuguese sentence, the small mountain village -aldeia- appears only once, linking the sentence by the participle 'chamada' and the preposition ' $a$ '. In the Chinese translation, however, we would have been better off repeating the mountain village, linking more modifiers and making the sentence fit the conventions of Chinese expression. In the case of ordinary teaching, the examples we give are limited to this and our students receive the same examples, then based on the new model mentioned, different students will get different teaching examples in the online teaching, for example, we will see examples like this, see Table 5.

The translation of Noé's example reads "Blue and white porcelain is a thin, polished or glazed tile. Blue and white porcelain is often used to decorate walls and is well known in Portugal." In the original Portuguese sentence, blue and white porcelain appears only once, and the explanation is too long, so if you translate it in one go, the sentence will be too long. Paul published his first book, The Hell Files, in 1982, but, unfortunately, it was poorly received." In this sentence, the repetition of "the book" completes the sentence and conforms to Chinese expressions. From the examples given above, we can see that the introduction and teaching of basic translation methods can be fully integrated into the choice of learners' interests. This is how all the content of the lessons is recreated and processed based on the learner's area of interest, forming a unified core of teaching.

\section{The Assessment Phase}

The assessment phase is the examination and evaluation of the specific competencies of the participants in the teaching model. As the module is delivered in both classroom and off-site settings, the specificity of the assessment is taken into account. The basic approach is that the trainee's total grade $=60 \%$ of the written exam + $40 \%$ of the usual grade $=100 \%$.

The written test consists of two parts: one part is an examination of the subject matter studied by the student, involving the content and extensions of the online teaching, and the translation questions are focused on the content of the subject matter of the student's own choice; the second part is the common assessment part, which is designed to test the student's ability to transfer and disperse, to see whether he or she can apply the methods and techniques learned to specific practices, and thus break through his or her own field of study. The second part of the examination is the common assessment, which is designed to test the participants' ability to transfer and disperse the skills they have learnt into practice, thus breaking the limits of their own field of study. A paper is worth 100 marks, with each section worth 50 marks.

There are two main aspects to consider in relation to the usual grades: the production of the teaching video for the minor, and the daily completion of the course, both of which account for $40 \%$ and $60 \%$ respectively. Please refer to Table 6 .

The first elements of Table 6 are available on the e-learning platform; the quality of the work submitted is judged by the instructor, who gives his or her opinion and comments. The number of articles collected refers to the amount of information collected by the students on the topics of their chosen major and minor courses, to see how much research and exploration they have done in the

Table 5. Example of teaching translation

\begin{tabular}{|c|l|}
\hline Noé & $\begin{array}{l}\text { O azulejo é uma peça de cerâmica vitrificada e/ou esmaltada, de pouca espessura, são recomendadas para serem } \\
\text { utilizadas como revestimento de parede, ganhando grande fame em Portugal. }\end{array}$ \\
\hline Elsa & $\begin{array}{l}\text { A edição do seu primeiro livro foi em 1982, Arquivos do inferno, que não teve repercussão desejada } \\
\text { infelizmente. }\end{array}$ \\
\hline
\end{tabular}

Table 6. Daily Performance Assessment Form for the first part of the assessment

\begin{tabular}{|c|c|c|c|c|}
\hline Name & $\begin{array}{c}\text { Number of courses } \\
\text { completed }\end{array}$ & $\begin{array}{c}\text { Number of assignments } \\
\text { submitted }\end{array}$ & $\begin{array}{c}\text { Quality of assignments } \\
\text { submitted }\end{array}$ & Number of articles collected \\
\hline Bruno & & & & \\
\hline Elsa & & & & \\
\hline Noé & & & & \\
\hline
\end{tabular}


area of interest, not only to serve the production of their teaching videos for their minor courses but also to help the instructor to accumulate information as a reserve of basic materials for future courses in this area. Through the combined assessment of these items, a fair score is given to the student.

\section{Conclusions}

The new model of teaching Portuguese-Chinese translation, which is based on the interest of students and is realized in the form of a pair of classes, is an innovative attempt in the construction of a new liberal arts ${ }^{[4]}$. Through the introduction of this model of translation teaching, we have found a way to increase students' interest in learning and to combine theory and practice, with good results in the corresponding teaching practice. In addition, the accumulation of overlaps in students' areas of interest will allow for the development of better internalized learning materials in the future, helping them to understand the integration of translation theory and practice, while the extension of non-overlapping areas of interest will allow teachers to enrich their future translation teaching with examples that will open up students' horizons and provide them with a multi-faceted understanding of the Portuguese-Chinese translation process. Although there are still certain shortcomings, the practical application and feedback of the model will make the teaching of translation based on the "interest" of the students more effective.

\section{References}

[1] Zhongyong Wang, Yingjing Xu The Construction and Practice of Multi-Dimensional Innovation and Entrepreneurship Competence System for Engineering Specialty $[\mathrm{J}]$. Frontiers in Educational Research, 2021, 4(3).

[2] Bill Koenig Rice Named No. 1 for Engineering Major Earnings Potential[J]. Manufacturing Engineering, 2015, 155(4).

[3] Jie Ban, Rethinking the Traditional Teaching of Russian Language in Universities in the Context of the New Liberal Arts - An Example from the Department of Russian Language of East China Normal University [J]. Education and Teaching Forum, 2020, 39(2).

[4] Zhibin Jiang, Strategic Innovation in the Cultivation of Foreign Language Talents in China in the Context of New Liberal Arts - An Exploration Based on the Practice of Shanghai International Studies University [J]. Technology Enhanced Foreign Language Education, 2019, 5(4). 